\title{
Single-sex Schooling and Labour Market Outcomes
}

\begin{abstract}
One quarter of the 1958 British Birth cohort attended single-sex secondary schools. This paper asks whether sex-segregated schooling had any impact on the experience of gender differences in the labour market in mid-life. We examine outcomes at age 42, allowing for socio-economic origins and abilities measured in childhood. We find no net impact of single-sex schooling on the chances of being employed in 2000, nor on the horizontal or social class segregation of mid-life occupations. But we do find a positive premium (5\%) on the wages of women (but not men), of having attended a single-sex school. This was accounted for by the relatively good performance of girls-only school students in post 16 qualifications, not by the wider range of subjects studied by both girls and boys at single-sex schools. Men's labour market attainments were more closely related to attending private schools and to parental class, suggesting that the intergenerational transmission of advantage, while not related to coeducation, is related to gender.
\end{abstract}

\author{
Alice Sullivan \\ Heather Joshi \\ Diana Leonard
}

Oxford Review of Education 2011, 37(3) 311-332. 


\section{Single-sex Schooling and Labour Market Outcomes}

\section{Introduction}

Are gender differences in the labour market reinforced - or counter-acted - by the declining practice of educating boys and girls in separate secondary schools? Coeducational schooling might have been expected to lead to greater mixing of the sexes in both further studies and professional life, but the opposite argument has also been made, especially for women: that coeducation discourages girls from pursuing traditionally male occupational paths. A further claim made by advocates of single-sex schooling for girls, such as the Girls' Schools Association is that single-sex schooling produces women who are more likely to be high-fliers and pursue leadership positions in their careers. Counter to this, it can be argued that the reason that so many 'high-flying' women have attended single-sex schools is due to the prevalence of single-sex schooling in the private and selective sectors.

Our study of the careers of the 1958 British cohort, for whom single-sex secondary schooling was still relatively common, has supported the view that it is co-educational schooling which exacerbates gender segregation, at least when it comes to academic qualifications (Sullivan et. al. 2009; Sullivan et. al., forthcoming). So, far from expecting sex-segregation in school to be reflected in a sex-segregated experience of the labour market in adult life, we would expect any association to be in the reverse direction, even allowing for the background advantages of the 1958 cohort which were associated with both attending single-sex schools and with employment in more integrated types of occupation as adults. 
Based on these findings, we may conjecture that co-educational rather than single-sex schools may have reinforced occupational gender stereotyping. If reducing the pressure towards gendered subject choices led to a better development of academic abilities at later stages, we should expect to see less gender segregated employment and higher remuneration to those people whose single-sex schooling had taken them on a gender a-typical route through education. It is also conjectured that for women to have gained access to "masculine" fields of study, a-typical work may have been more remunerative than it was for men following their interests into female dominated parts of the labour market, since the feminisation of occupations tends to be linked to lower status and pay.

The labour market in Britain during the last quarter of the twenty-first century was a major theatre of gendered differences between the lives of men and women. Women had lower rates of participation in paid work and on average shorter hours of work when in a job. Men's and women's employment also differed in that most were employed in jobs typically undertaken by their own gender. Women were less likely to occupy 'top' jobs, and their pay was on average lower than men's (Pullinger 1998, Joshi et. al., 2007). This meant that for the 1958 cohort studied here, the proportion of men who were full-time employees (around 74 per cent) was more than double that of women, 33 per cent, at age 33 (Woods et. al. 2003); most employees were in gender-segregated jobs (78 percent of women and 16 percent of men were in occupations mainly done by women), and women's wages at 33 were $32 \%$ below mens' (Joshi and Paci 1998). However, all of these contrasts were smaller for women with more education (Woods et. al. 2003, Dearden et al, 2002), which suggests that the increased education received by women in 
these post-war cohorts would contribute to a diminution of gender differences in employment. This paper investigates whether the sex-segregation of education itself contributed to the relative fortunes of men's and women's careers in the last quarter of the $20^{\text {th }}$ century. In doing so, we have also uncovered new evidence on gender differences in the intergenerational transmission of economic advantage.

\section{Literature}

The question on whether single-sex schooling has any impact on academic and other outcomes remains contested, and the debate has been revived by concerns regarding the gender-gap in examination attainment. Recent reviews of the evidence have noted the difficulty of comparing like with like, and have commented on the small number of studies that use adequate statistical controls (Mael et al., 2005, Smithers \& Robinson, 2006). Our study has found that girls who attended single-sex schools achieved better examination results at age 16 than their co-educated peers, though there was no difference for boys (Sullivan et. al. forthcoming). Single-sex schooling was not associated with any difference in the chances of obtaining post-16 qualifications for either sex either at A level or the highest level attained by age 33, once the sector of the school (private, grammar, secondary modern or comprehensive) was taken into account. This is consistent with the pattern of results reported by Dearden et al (2002) regarding qualifications at age 33. However, we found that both sexes were more likely to gain qualifications at both $\mathrm{O}$ and $\mathrm{A}$ level, in subjects associated with the opposite sex - maths, physics and chemistry for girls, English and modern languages for boys - if they attended a single-sex 
school. This leads us to the present question of whether these educational differentials feed through into later labour market outcomes.

There is precious little empirical evidence on the question of whether single-sex schooling is linked to labour-market participation or success for either sex. Dearden et al ( 2002) find that single-sex schooling makes no significant difference to the probability of either men or women being employed at age 33, once school sector is accounted for. Neither do they find any impact either way of men having attended a single-sex school on wages at 23 or 33. They do find a significant effect of having attended a girl's school on women's wages at 33 (a $6 \%$ premium) but this is accounted for when qualifications are included in the model. Mael et. al.'s (2005) systematic review of research on single-sex and coeducational schooling finds only two studies which examine labour market outcomes, and both of these look only at unemployment. Marsh's (1991) study of Catholic high schools found no difference in the rates of post-secondary unemployment between graduates of single-sex and co-educational schools. However, a study of single-sex and coeducational high schools in New Zealand (Woodward et al., 1999) found higher unemployment rates in the two years after graduation for both sexes if they had attended coeducational schools. Both of these papers examine outcomes shortly after the completion of schooling. By contrast, we examine outcomes at age 42 , an age when career development is typically advanced, and most women are in employment ( 80 percent vs. 68 percent at age 33, Woods et. al. 2003). Also, we are able to include the gender-typing of qualifications and occupations. The study we report on here is unusual in taking a lifecourse perspective on the question of single-sex and coeducational schooling, allowing us to examine outcomes at later 
ages, when the subjects of the research had had time to accrue labour market experience and establish themselves in a particular sector of economic activity

\section{Research Questions}

Educational outcomes are linked to labour market outcomes. We investigate whether there are differences between those men and women who went to single-sex and mixed schools in terms of: 1. labour market participation, 2. occupational attainment, and 3. hourly wages; controlling in each case for childhood circumstances and characteristics prior to entry to secondary school and qualifications attained. Besides the various ways of ranking occupations 'vertically', we are particularly interested in the degree to which an occupation is typically done mostly by men or by women (Hakim, 1998, Rubery \& Fagan, 1993). We will be able to assess whether those who attended single-sex schools were more or less likely to have a gender-segregated experience of the labour market, by ranking occupations according to their degree of gender segregation. Although the cohort studies do not include data on workplace segregation, we can derive the general level of gender specialisation in a 3-digit occupational code from census information see (Blackwell, 2001). For National Child Development Study (NCDS) members who were in employment in 1991, 69\% of women (and 13\% of men) were in occupations where (in the 1991 census) more than $50 \%$ of workers were women. For women part-time employees, this figure rises to $90 \%$ (Paci et. al. 1995). Feminised occupations tended to be low paid, but the interest here is whether 'separation' at school is reflected in separation in occupations, whether or not 
that in turn contributes to the gender pay gap. Although for women these labour market outcomes are linked to family formation, we have found no link between single-sex schooling and family formation (Leonard, Joshi and Sullivan 2007) so this paper does not bring this factor into the account.

We examine whether single-sex schooling during the secondary years can be linked to the following outcomes at age 42 .

1. Socio-economic status

2. Gender-segregation of occupation

\section{Wages}

The wage variable can be thought of as providing more finely tuned evidence on vertical segregation, as the 10-fold occupational categories of National Statistics Socio-Economic Classification (NS-SEC) cannot detect progress up a career ladder within these broad categories. Being in occupation done mainly by one's own sex rather than one done by both men and women side by side (our second outcome) is not necessarily an indicator of success or failure, but for women at least it can be associated with low pay. Combining our analysis of occupation and wages can throw some light on this. 
The model used to predict each outcome includes a set of background factors, including the characteristics of the family of origin, the cohort member's test-scores, and school sector, in addition to whether or not the school at 16 was coeducational. In cases where we find an independent association of single-sex schooling with an adult outcome we also investigate post16 variables which might have explained it. The model which does not include the cohort members own attainments can be thought of as a measure of intergenerational transmission.

\section{Data and Methods}

The National Child Development Study (NCDS) is a longitudinal study of a single cohort born in a particular week in 1958 in Britain. The survey continues to follow up the cohort members at regular individuals.

The initial sample was designed to be nationally representative of all children in Britain, and achieved a sample size of 17,414 (Bynner and Joshi 2007). Immigrants with the relevant birthdays were recruited in the childhood sweeps. By the third follow up (sweep 3), when the children were aged 16, 14,761 respondents remained in the study. Hawkes and Plewis' (2006) examination of attrition and non-response in the NCDS finds few significant predictors of attrition, wave non-response, and missing education data. This supports the assumption of ignorable missingness. Neither parental education nor social class were significant predictors of non-response. The distribution of educational qualifications gained by the cohort members by age 33 was closely in line with other data sources (Dale \& Egerton, 1997). The relationship of qualifications to family background, in both this and the 1970 cohort study is well documented, for example by Bynner and Joshi (2002). 
The NCDS cohort experienced a state secondary education system that was in transition from the tripartite system to the comprehensive system. Under the tripartite system, children sat an exam at age 11 (called the eleven-plus) which determined whether they would attend an academically selective grammar or technical school, or a secondary modern school, designed for the majority of students. Comprehensive schools were intended to replace this selective system with allability schools. Fifty-eight $\%$ of the NCDS respondents attended comprehensive schools, but $11 \%$ still attended grammar and technical schools, $22 \%$ attended secondary modern schools, and $6 \%$ attended private and direct grant schools. Private schools are fee-paying schools. direct grant schools were fee-paying, but had a proportion of state-funded places. Henceforth, we refer to grammar and technical schools as 'grammar schools', and private and direct grant schools as 'private schools'.

We exclude from our analyses the small proportion of students who attended schools classified as special or 'other' (the other category includes miscellaneous schools such as hospital schools) We also exclude respondents lacking in information on school sector or school sex at age 16, leaving us with a sample of 12320 in contact at age 16,8785 of whom also provided data at age 42. Single-sex schooling was far more common than it is today. The proportion of students at single-sex schools ranged from $78 \%$ at private schools to $11 \%$ at comprehensives. Taken as a whole, a quarter of the cohort attended single-sex schools at age 16. This provides an advantage for our analysis, as, in school systems where single-sex schooling has become the preserve of a small minority, this makes it very difficult to compare like with like (Baker et al., 1995). In our 
study, single-sex schooling and selective education are not confounded, as a majority of singlesex cohort members attended the largest, comprehensive, category of schools.

Previous studies of the effects of single-sex schooling have been criticised for inadequate allowance for prior attainment and family background (Lee \& Bryk, 1986, Lee \& Bryk, 1989, Marsh, 1989). Given the concentration of single-sex schools in the private and selective sectors, it is important to control for such sources of selectivity. The NCDS gives exceptionally rich information on various aspects of the respondents, their schools and their parents, allowing crucial confounding variables to be controlled. The parents were interviewed when the cohort was aged $0,7,11$ and 16, providing information on social background, age when parents left full-time education, and other characteristics.

As children, the cohort members provided data directly through tests and questionnaires administered at school at the ages of 7,11 and 16. From the age of 16 onwards, the cohort members themselves were interviewed. Extensive information on examination results was collected directly from the schools.

In preliminary analyses of attendance at a single-sex school we found little difference, apart from region, in the prior characteristics of students at single-sex and co-educational schools within each school sector. This suggests that the danger of spurious results due to differences between the pupil populations of single-sex and co-educational schools is minimal, provided that school sector and region are controlled. This finding may seem surprising, but makes sense in the context of schooling before era of 'parental choice', and school league tables. 
Although we have both individual-level and school-level data, we are not able to identify whether students attended the same school as other members of the sample. The sample is not clustered, i.e. students are not sampled within schools. The sample consists of all children born in Britain in the relevant week. Many schools would be represented by a single cohort member. It is therefore neither possible nor necessary to apply a multilevel statistical model to the NCDS data. A further caveat is that, due to the small numbers of ethnic minority individuals included in the NCDS, it is not possible to conduct analyses according to ethnic group.

The following variables are included in all models.

- School sex

- Pupils'sex

- School sector.

- Region - data collected at age 16. This is included as a control variable, as it is a predictor of attending a single-sex school.

- Fathers' social class - age 11. Seven category version of the Hope-Goldthorpe scale. In the case of missing values for this variable (2 278 cases) we imputed the value from information on the father's social class at the two previous sweeps of the study, which left us with 355 cases with missing information on this variable. Missingness on this variable often predicts equally or even more negative outcomes than even the lowest social class category, therefore it is likely that data is missing 'Not at Random' (Rothon, 2007). These cases are treated as a separate category. 
- Parental educational level - age at which, mother or father left full-time education, whichever is higher. 2657 missing values are treated as a separate category.

- Test scores at age 7 and 11 (transformed into $\mathrm{Z}$ scores). We impute missing values on each of the test scores from the full set of test scores, using the Expectation-Maximization algorithm (Schafer, 1997).

Early test scores, social class background and parental education are all powerful predictors of educational attainment, and previous studies of single-sex and coeducational schooling have been criticised for omitting such measures.

\section{Analyses}

We now turn to the question of whether the labour market experiences of the men and women in our sample were linked to whether the school they attended at age 16 was single-sex or coeducational. These analyses include the 8785 respondents who were present at both the age 42 and age 16 samples after excluding individuals who attended special or other schools.

\section{Labour market participation:}

We first looked at participation in paid work at age 42 and, whether jobs were full or part-time. This is not the main focus of our paper, but it is important to establish whether single-sex schooling was linked to labour market participation in order to be able to interpret the results of our models regarding horizontal and vertical labour market segregation and stratification. $45 \%$ of women born in 1958 were in full-time employment at age $42,35 \%$ were in part-time employment, and $12 \%$ 
were at home looking after their families. ( $88 \%$ of men were in full-time work). We modelled the likelihood of being in employment (whether full or part-time), as opposed to any other labour market status, using binary logistic regression. This model is shown as an appendix (Table A1). Neither single-sex schooling nor school sector were significant predictors for either sex. We tested for an interaction between single-sex schooling and school sector, in order to see whether singlesex schooling made a difference given the type of school under consideration. We found no significant interaction effect, for this or any of the other outcome examined in this paper. Overall model fit was poor, and weaker for women than for men. This finding does however suggest that the focus of our subsequent analyses on respondents who were in employment will not suffer from selection bias with respect to single-sex education.

We also modelled the chances of employed women being in part-time as opposed to full-time work, using binary logistic regression. There was no significant effect of having attended a singlesex school, nor of any other variables of interest, so the details are not reported (available from authors on request). Socio-economic status (entry to the 'salariat').

Table 1 shows the socio-economic class of the cohort members' current or most recent occupation at age 42. Women were under-represented among employers, managers and professionals, as well as skilled manual and own-account workers. Women were over-represented among junior nonmanual and personal service workers and ancillary professionals (this category includes teachers and nurses).

\section{TABLE 1}


Although this occupational classification (NS-SEC) cannot be viewed as a straightforward hierarchy, the first four categories, comprising employers, managers and professionals are generally seen as relatively high status, and often referred to as the 'service-class' or 'salariat'. We also include 'ancillary professionals' (such as teachers and nurses) in this category, as many women graduates enter the ancillary professions. We modelled entry to the salariat by age 42 in order to assess whether single-sex schooling was linked to this outcome, conditioning on controls for prior characteristics (Table 2).

TABLE 2

Single-sex schooling was not a significant predictor of arrival in the salariat for either sex.

Private schooling was significantly linked to access to the salariat for men but not (at conventional levels of significance) for women. Father's class and parental education were also significant for men but not for women. Early test scores at age 7 (especially arithmetic) were significant for women, but not men, while test scores in reading and maths at age 11 were highly significant for both sexes. Taking this as a measure of intergenerational mobility, the women appear to have had a more meritocratic experience than the men, for whom father's occupation, parental education and private schooling are all significant independent predictors of attained occupational status.

Gender segregation of occupations 
Many occupations are highly sex-segregated. In Hakim's classification of occupational segregation (Hakim, 1998), occupations which are $25 \%$ to $54 \%$ women are described as 'integrated'. (Her argument is that there are fewer women than men in the labour market, hence $25 \%$ women is considered integrated, but $25 \%$ men would be considered women-dominated.) Table 3 shows the proportions of men and women from single-sex and co-educational schools who were in women-dominated, men-dominated or integrated jobs at age 42 . The sex segregation index is based on 103 separate occupations and workers of all ages in the $1991 \mathrm{~GB}$ census Household Sample of Anonymised Records (Elliott, 2005).

\section{TABLE 3}

This gives the impression that men and women who went to single-sex schools went on to have a less sex-segregated experience of the labour market, as single-sex educated men and women were relatively likely to be found in 'integrated' occupations. However, the integrated occupations also tended to be higher status than the sex-segregated occupations. Thus, the fact that the single-sex schools were found disproportionately in the private and grammar sectors largely accounts for the association with single-sex schooling.

In regressions controlling for students' background characteristics no significant effect of singlesex schooling on occupational segregation at age 42 was found. We modelled the likelihood of the cohort members being in: 1 . Integrated; 2. Male dominated; and 3. Female dominated occupations, using binary logistic regression, running separate regressions for men and women. The results for the outcome of integrated occupational status are shown in table 4. 


\section{TABLE 4}

For men, attending a private school, having at least one parent educated beyond age 18, and good reading scores at 11 , were significant positive predictors of being in an integrated occupation at 42. Fathers' social class was also relevant, although only the small employer and manager category reached statistical significance. However, for women, the model fit was poor, and only some cognitive tests at 7 and 11 predicted being in an integrated occupation.

For women, being in a female dominated occupation at age 42 was negatively linked to two of the tests at age 7 and maths and reading at age 11, and not related to any other variable in the model. For men, the model fit was even poorer and there were no significant predictors of this outcome. Similarly there was a very poor fit for the model predicting employment in a male dominated job. For men, having a male-type occupation, private or grammar schooling, a graduate parent and high reading scores at age 11 were negative predictors of being in a maledominated occupation at age 42 , but none of these predictors were significant for women. These models are available on request.

So, for women, low test scores were linked to female-dominated occupations, while for men, low test scores were linked to male-dominated occupations. For both sexes, but especially for women, high test scores were linked to integrated occupations. 
The negative predictors of same-sex segregated employment can be understood in terms of the lower levels of gender segregation of occupations in the employer and manager classes (although the professional occupations were largely male-dominated at this time). Men in manual jobs were most likely to be in male-dominated occupations, while women in personal service jobs were typically in female-dominated occupations.

\section{FIGURE 1}

Figure 1 plots the distribution of cohort members jobs by the 10-fold socio-economic classification of those jobs and the sex-segregation of the occupations within them. It shows that integrated occupations are more common in the top four salariat occupations than elsewhere in the occupational structure, although they do not form the majority of any one socio-economic group even here. Outside the salariat, sex segregated categories dominate. Male type jobs are most common in skilled manual work and female type jobs account for the whole of the personal service category.

The fact that single-sex schooling had no impact on occupational segregation for either sex may seem surprising given that students at single-sex schools pursued less gender-typical academic paths than students in co-ed schools. However, simply taking a gender-atypical educational option does not lead directly into either gender-atypical or integrated employment. The path between qualifications and occupational outcomes is itself highly gendered.

Thus the segregation of employment is far from perfectly associated with sex differences in 
subject of qualification, and this weakens the link between education and employment segregation.

The categorisation for the subject areas of the cohort members' highest qualifications is taken from Dale and Egerton (1997). Our definition of an 'integrated' subject is $40-60 \%$ female. For example, engineering is defined as male ( $94 \%$ male), nursing is 'female' at the opposite end of the spectrum (94\% female), while biological sciences (53\% female) are integrated. This is consistent with the highly gendered patterns of participation that have been found across the education system (Thomas, 1990).

Occupational segregation is more extreme than educational segregation. This supports the view that men and women face ongoing social pressure (such as discrimination) to make genderappropriate 'choices', rather than later outcomes being entirely shaped by early gender-role socialisation.

As shown in Figure 2, Men were more likely to go into male-dominated occupations, even if they had female-dominated qualifications, and women were more likely to go into femaledominated occupations, even if they had male-dominated qualifications. Nearly $50 \%$ of women with male-dominated qualifications went into female-dominated occupations. 'Integrated' type qualifications only led to 'integrated -type occupations for a minority of each sex (29\% female, $31 \%$ male).

\section{FIGURE 2}


The sex-type of qualifications is nevertheless associated with that of occupations (table 5). Men with female-dominated qualifications are about three times more likely than other men to be in a female dominated occupation ( $31 \%$ vs $10 \%$ ), and men with male-dominated qualifications are most likely to be in male-dominated occupations ( $67 \%$ vs $57 \%$ and $38 \%$ from integrated and female-type qualifications respectively). Women with male-type qualifications are more likely than others to be in male-type jobs, but there are only just over one in 5 (21.5\%) of this small group in male-type jobs. Women with female-type qualifications are most likely to be found in female type jobs ( $79 \%$ vs $49 \%$ male and $61 \%$ integrated qualifications).

\section{TABLE 5}

The fact that single-sex schooling was associated with gender-atypical qualifications, but not with gender-atypical occupations is less surprising once we take on board the fact that there were strong pressures towards gender-typical jobs, even for men and women with gender-atypical qualifications (Glover, 2000). For example, a high proportion of women science graduates went into school teaching. Dale and Egerton (1997) (p.8) show that, among the NCDS women, 34\% of physics graduates and $30 \%$ of maths graduates became teachers. The figures for men were $7 \%$ and 5\% respectively. Among language graduates, $36 \%$ of both men and women went into teaching, and for humanities graduates, $16 \%$ of men and $18 \%$ of women went into teaching.

\section{Wages}


Women in paid employment were paid substantially less than men at age 42; but across school sectors, women who had attended single-sex schools gained higher wages. Among women who had attended Comprehensive schools, those who had attended single-sex schools earned a mean hourly wage of $£ 8.33$, compared to $£ 7.92$ for those who had attended co-educational schools.

Regression analyses confirm that, conditioning on background controls, there was a statistically significant positive association between single-sex schooling and wages for women, but not for men (tables 6 and 7). Private schooling was positive for men. For women, private and grammar schooling were positive and secondary modern schooling negative. The link between fathers' social class and wages was stronger for men than for women, while parents' education was more significant for women. Although there were some differences in the predictive power of the early test scores for men compared to women, non-verbal reasoning and reading at age 11 stand out as the most significant test scores for both sexes.

\section{TABLES 6 AND 7}

It may seem surprising that single-sex schooling should have had a positive impact on women's wages, despite having no statistically significant impact on access to the salariat or to integrated or male-dominated occupations. It is likely that these variables are too crude to pick up the effect of pay hierarchies within occupations identified by the more fine-grained wages variable.

Having established a link between single-sex schooling and higher wages for women, the question arises whether this association is due to differences in the qualifications achieved by 
girls at single-sex and co-educational schools. In previous work (Sullivan et. al. forthcoming) we found that girls were considerably more likely to achieve five or more A-C O-level passes (or CSE equivalent) at single-sex than at co-educational schools. There was no effect for boys. In addition, girls at single-sex schools gained more passes in maths, physics and chemistry than coeducated girls, while boys at single-sex schools gained more passes in English and modern languages than co-educated boys. So, is the wage premium for women who had attended singlesex schools due to their superior overall examination performance at age 16 , and within that, their superior performance in maths and sciences?

To address this question, we add additional variables to the model: Achievement of 5+O level A-C or CSE grade 1 passes; Number of passes in maths, physics or chemistry (ranging from 03); and Number of English and modern language passes (ranging from 0-3).

Model 2 shows that having 5+ O levels is a highly significant predictor of wages at age 42 for both men and women. For men, having three maths or science passes was highly significantly positive, while for women, this estimate was of more borderline significance. Conversely, having one English or modern language pass was highly significant for women, but of borderline significance for men.

In this model, the single-sex coefficient for girls is no longer significant at the 0.05 level. This is the case even in an alternative specification of the model omitting the subject passes. This suggests that single-sex girls' advantage in overall $\mathrm{O}$ level attainment is sufficient to explain the higher wages they achieved in later life. This is despite the fact that, as we have shown in previous work (Sullivan et. al. forthcoming) girls who had attended single-sex schools did not 
maintain their advantage over co-educated girls in later qualifications: they were no more likely to gain A levels or a degree. It may seem surprising that superior performance in examinations at age 16 could be sufficient to explain the wage gap between women who had attended single-sex vs. co-ed schools. However, only a minority (35\%) of this cohort stayed on in education post-16, so O levels would have been a very important indicator of attainment for employers.

We added a final model including the highest qualification at age 33, and the sex type of this qualification according to its subject area, for those with further qualifications and above. We have previously established that students who had attended co-educational schools were relatively likely to gain qualifications in subjects that were dominated by their own sex. This led us to speculate that the greater tendency of girls from single-sex schools to pursue maledominated qualifications may provide them with an advantage in the labour market. However, model 3 shows that, while the NVQ level achieved by age 33 is a highly significant determinant of wages for both sexes, the 'sex' of the subject discipline of the highest qualification is not a significant predictor of wages for women. For men, female dominated qualifications are predictive of lower wages. These findings are in contrast to the results reported by Katz-Gerro and Yaish (2003) regarding Israel in the 1980s. They found a wage premium for individuals with sex-atypical qualifications, and posited a plausible argument to account for this. It is rational for employers to reward individuals with sex-atypical qualifications, they suggest, because these individuals send a strong labour market signal regarding their commitment. The fact that, for this British cohort, female qualifications were penalised for men, while, for women, there was no effect of the sex-type of their qualifications, may suggest that their employers were not purely rational profit-maximisers, but also enforced gendered labour market norms. 
When we also included the sex segregation of the job at 42 to extend Model 3 (not shown) the estimates for single-sex schooling remained insignificant, although they verged on significance for women, suggesting the possibility of a very minor impact of having been to a girls school in helping to avoid the low pay in feminized jobs. Both sexes were worse paid in their own type of job than in integrated jobs, but the female penalty for 'feminine' jobs is much greater than the male penalty for 'masculine' jobs. Therefore we can conclude that the influence of single-sex schooling for girls did not significantly work through either the desegregation of subject choice or the type of job held. While it appeared to influence the sex-type of subjects this did not lead to the sex-typing of jobs. While the latter is linked to rates of pay it is not linked to the sex composition of the school

It is also noteworthy that in all three models there are few differences between men and women in the estimated impact of the cohort members' own attainments in test scores or exams on adult wages until it comes to model 3, where women gain more value from their highest qualification and men do better from avoiding female-type subjects.

\section{Conclusions}

While the men and women of the 1958 cohort had different experiences of paid work and its remuneration at age 42 , we found little evidence that having attended a single-sex secondary school had a direct impact on labour market success, or occupational segregation. For men, we find a lasting advantage from having attended a private school, but nothing directly attributable 
to having been educated with or without girls. Among girls, we did find a long-term legacy of having been to a single-sex rather than a co-educational school. Women who had been to girls' schools received a pay premium of about $5 \%$ at age 42 compared to other women. This advantage was accounted for by their superior examination results at age 16. Their less sex-typed subject choices at A level and higher education did not translate either into a pay premium or a less sex-segregated occupation.

The wider range of subjects which the girls at girls' schools went on to study belies the notion that girls' schools were either reflecting or inculcating a taste for sex segregation. In fact, these results suggest that the gendered nature of labour market (and other) institutions is the dominant feature of adult experience rather than any legacy of single-sex schooling. It is an irony that, while it is often argued against single-sex schooling that single-sex environments are 'unnatural' for young people, gender-segregated environments are seen as quite normal in adult life.

Although these models were not specifically designed to quantify either the extent of intergenerational transmission of economic and social advantage, nor the extent of unequal treatment of men and women in the labour market, we have established that the latter is partly attributable to men gaining more of an advantage than women from having attended private schools and from having fathers with higher social class jobs. This in turn means that the study of social mobility needs to take account of gendered processes. In this cohort women had a more meritocratic experience than men. This is in line with previous evidence on the higher returns to education for women than for men (Vignoles et al., 2002). 
Our current elite of the generation who attended secondary school in the 1970s is dominated by graduates of single-sex schools, which will be less the case for future elites. An understanding of the educational trajectories of this generation of men and women, who have been tracked into their maturity and middle-age, is relevant for understanding the gendered patterns of their lives, in the labour market and elsewhere, and how the single-sex schooling in the 1970s will cast a long shadow even as it becomes an outdated experience for teenagers in the twenty-first century

Acknowledgements: This work was funded by ESRC Award RES-000-22-1085. Thanks are due to the National Child Development Study survey members for their contribution over many years. Thanks also to the ORE reviewers for their comments. 


\section{References}

Baker, D. B., Riordan, C. \& Schaub, M. (1995) The effects of sex-grouped schooling on achievement: The role of national context. Comparative Education Review, 39, 468-482.

Blackwell, L. (2001) Women's work in the uk: Official statistics and the 1980 reclassification of occupations. Journal of the Royal Statistical Society Series A-Statistics in Society, 164(2), 307-326.

Bynner, J., \& Joshi, H. (2007). Building the evidence base from longitudinal data: The aims, content and achievements of the British Birth Cohort Studies. Innovations, 20(2), 159-179.

Bynner, J and Joshi, H. (2002) Equality and Opportunity in Education: evidence from the 1958 and 1970 Birth cohort Studies. Oxford Review of Education 28, 405-425.

Dale, A. \& Egerton, M. (1997) Highly educated women: Evidence from the national child development study, (London, HMSO).

Dearden, L., Ferri, J. and Meghir, C. (2002) The effect of school quality on educational attainment and wages. The Review of Economics and Statistics, 84(1), 1-20.

Elliott, J. (2005) Comparing occupational segregation in great britain and the united states: The benefits of using a multi-group measure of segregation. Work, Employment and Society, 19(1), 153-174.

Glover, J. (2000) Women and scientific employment, (Basingstoke, Macmillan).

Hakim, C. (1998) Social change and innovation in the labour market, (Oxford, Oxford University Press).

Hawkes, D. and Plewis, I. 2006. Modelling Non-Response in the National Child Development Study. Journal of the Royal Statistical Society, A., 169: 479-491.

Joshi, H., Makepeace, G. and Dolton, P. 2007. 'More or less unequal? Evidence on the pay of men and women from the British Birth Cohort Studies'. Gender, Work and Organization 14: 3751.

Joshi, H. and Paci, P. 1998. Unequal Pay for Women and Men. Cambridge, Mass.: MIT Press. Katz-Gerro, T. and Yaish, M. 2003. 'Higher Education: More is Better? Gender Differences in Labor Market Returns to Tertiary Education in Israel'. Oxford Review of Education 29, 571-592.

Lee, V. E. \& Bryk, A. S. (1986) Effects of single-sex secondary schools on student achievement and attitudes. Journal of Educational Psychology, 78(381-395.

Lee, V. E. \& Bryk, A. S. (1989) Effects of single-sex schools - response. Journal of Educational Psychology, 81(4), 647-650.

Leonard, D., Joshi, H. and Sullivan, A. 2007. Single-sex and Co-educational Schooling: Lifecourse consequences? ESRC.

Mael, F., Alonso, A., Gibson, D., Rogers, K. \& Smith, M. (2005) Single-sex versus coeducational schooling: A systematic review, (Policy and Program Studies Service, US Department of Education).

Marsh, H. W. (1989) Effects of single-sex and coeducational schools - a response to lee and bryk. Journal of Educational Psychology, 81(4), 651-653.

Marsh, H. W. (1991) Public, catholic single-sex, and catholic coeducational high-schools - their effects on achievement, affect, and behaviors. American Journal of Education, 99(3), $320-356$. 
Paci, P., Joshi, H. and Makepeace, G. (1995) Pay gaps facing men and women born in 1958: differences within the labour market ${ }^{e e}$. In J. Humphries and J. Rubery (Eds.) The Economics of Equal Opportunity, Manchester: Equal Opportunities Commission, 87-112.

Pullinger, J. (Ed.) Social Trends (28) (London, Office for National Statistics).

Rothon, C. (2007) Can achievement differentials be explained by social class alone?: An examination of minority ethnic educational performance in England and Wales at the end of compulsory schooling. Ethnicities, 7(3), 306-322.

Rubery, J. \& Fagan, C. (1993) Occupational segregation of women and men in the european community, (Brussels, European Commission).

Schafer, J. L. (1997) Analysis of incomplete multivariate data, (London, Chapman and Hall).

Smithers, A. \& Robinson, P. (2006) The paradox of single-sex and co-educational schooling. Report for University of Buckingham.

Sullivan, A., Joshi, H. and Leonard, D. (forthcoming) 'Single-sex Schooling and Academic Attainment at School and through the Lifecourse'. American Education Research Journal. http://aer.sagepub.com/cgi/rapidpdf/0002831209350106v1

Sullivan, A. 2009. 'Academic self-concept, gender and single-sex schooling' British Educational Research Journal 35(2) 259-288.

Thomas, K. (1990) Gender and subject in higher education, (London, Taylor and Francis).

Vignoles, A., Dearden, L., Mcintosh, S. \& Myck, M. (2002) The returns to academic, vocational and basic skills in britain. Bulletin of Economic Research, 54(3), 249-274.

Woods, L., Joshi, H., Dolton, P. and Makepeace, G. (2003) The World of Paid Work. In Ferri, E., Bynner, J. and Wadworth, M (eds), Changing Britain, Changing Lives: Three Generations at the End of the Century. London: Institute of Education

Woodward, L. J., Fergusson, D. M. \& Horwood, L. J. (1999) Effects of single-sex and coeducational secondary schooling on children's academic achievement. Australian Journal of Education, 43(142-156. 


\section{Tables and Figures}

Table 1: Socio-economic class of cohort member at current or most recent job by age 42 by gender

\begin{tabular}{|l|r|r|r|r|r|}
\hline \multirow{2}{*}{} & \multicolumn{2}{|c|}{ Men } & \multicolumn{2}{c|}{ Women } & Total \\
\cline { 2 - 6 } & \multicolumn{1}{|c|}{$\mathrm{N}$} & \multicolumn{1}{c|}{$\%$} & \multicolumn{1}{c|}{$\mathrm{N}$} & \multicolumn{1}{c|}{$\%$} & $\mathrm{~N}$ \\
\hline Employers and managers large & 770 & 18.4 & 381 & 9.2 & 1,151 \\
\hline Employers and managers small & 586 & 14.0 & 382 & 9.2 & 968 \\
\hline Professionals & 306 & 7.3 & 128 & 3.1 & 434 \\
\hline Ancillary professionals & 336 & 8.0 & 670 & 16.2 & 1,006 \\
\hline Own account & 391 & 9.3 & 182 & 4.4 & 573 \\
\hline Foremen and supervisors & 394 & 9.4 & 310 & 7.5 & 704 \\
\hline Junior non-manual & 279 & 6.7 & 1,109 & 26.8 & 1,388 \\
\hline Personal service & 31 & 0.7 & 436 & 10.6 & 467 \\
\hline Skilled manual & 674 & 16.1 & 57 & 1.4 & 731 \\
\hline Unskilled manual & 420 & 10.0 & 477 & 11.5 & 897 \\
\hline Total & 4,187 & 100.0 & 4,132 & 100.0 & 8,319 \\
\hline
\end{tabular}


Table 2: Logistic regression, Entry to salariat by age 42 (Based on current or previous job)

\begin{tabular}{|c|c|c|c|c|}
\hline & Men & & Women & \\
\hline & Odds Ratio & $\mathrm{P}$ & Odds Ratio & $\mathrm{P}$ \\
\hline Single sex & 0.944 & 0.558 & 1.008 & 0.940 \\
\hline School Sector & & 0.151 & & 0.257 \\
\hline Private & 1.443 & 0.023 & 1.376 & 0.065 \\
\hline Grammar & 1.109 & 0.411 & 1.203 & 0.156 \\
\hline Secondary Modern & 1.075 & 0.431 & 1.092 & 0.431 \\
\hline Father's class & & 0.000 & & 0.329 \\
\hline Emplovers, managers, large & 2.582 & 0.000 & 1.217 & 0.348 \\
\hline Employers, managers, small & 2.167 & 0.000 & 1.191 & 0.241 \\
\hline Professional & 1.840 & 0.000 & 1.374 & 0.089 \\
\hline Own account & 1.360 & 0.127 & 1.103 & 0.672 \\
\hline Junior Non-manual & 1.539 & 0.001 & 0.958 & 0.770 \\
\hline Skilled manual & 1.209 & 0.059 & 0.971 & 0.800 \\
\hline Missing & 1.341 & 0.218 & 1.401 & 0.239 \\
\hline Parents' age left education & & 0.004 & & 0.246 \\
\hline $19+$ & 1.687 & 0.000 & 1.334 & 0.058 \\
\hline $17-18$ & 1.008 & 0.943 & 1.241 & 0.080 \\
\hline 16 & 1.055 & 0.581 & 1.029 & 0.802 \\
\hline Missing & 1.056 & 0.598 & 1.066 & 0.600 \\
\hline Childhood Cognitive scores & & & & \\
\hline Arithmetic 7 & 1.031 & 0.486 & 1.142 & 0.006 \\
\hline Reading 7 & 1.088 & 0.113 & 0.875 & 0.055 \\
\hline Draw-a-man 7 & 0.995 & 0.902 & 1.089 & 0.046 \\
\hline Non-verbal reasoning 11 & 1.125 & 0.056 & 0.921 & 0.261 \\
\hline Reading 11 & 1.159 & 0.007 & 1.190 & 0.009 \\
\hline Maths 11 & 1.412 & 0.000 & 1.349 & 0.000 \\
\hline Constant & 0.291 & 0.000 & 0.227 & 0.000 \\
\hline $\mathrm{N}$ & 4,187 & & 4,130 & \\
\hline R2 & 0.148 & & 0.064 & \\
\hline
\end{tabular}

Region at 16 also included but not shown. 
Table 3: Occupational segregation (Hakim's classification) age 42

\begin{tabular}{|l|r|r|r|r|r|r|r|r|}
\hline \multirow{3}{*}{ Job segregation } & \multicolumn{4}{|c|}{ Men } & \multicolumn{4}{c|}{ Women } \\
\cline { 2 - 9 } & \multicolumn{2}{|c|}{ Co-ed } & \multicolumn{2}{|c|}{ Boys' school } & \multicolumn{2}{c|}{ Co-ed } & \multicolumn{2}{c|}{ Girls' school } \\
\cline { 2 - 9 } & Count & \% & Count & $\%$ & Count & $\%$ & Count & $\%$ \\
\hline Female-dominated & 379 & 12 & 134 & 13 & 2306 & 76 & 784 & 69 \\
\hline Integrated & 640 & 20 & 294 & 29 & 488 & 16 & 244 & 21 \\
\hline Male-dominated & 2230 & 69 & 589 & 58 & 253 & 8 & 116 & 10 \\
\hline TOTAL & 3249 & 100 & 1017 & 100 & 3047 & 100 & 1144 & 100 \\
\hline
\end{tabular}


Table 4: Logistic regression: integrated occupation at 42 (current or previous job)

\begin{tabular}{|l|l|l|l|l|}
\hline & Men & & Women & \\
\hline & Odds Ratio & Sig. & Odds Ratio & Sig. \\
\hline Single sex & 1.038 & 0.730 & 1.027 & 0.813 \\
\hline & & & & \\
\hline School Type & & 0.008 & & 0.587 \\
\hline Private & 1.578 & 0.005 & 1.192 & 0.343 \\
\hline Grammar & 1.195 & 0.184 & 0.965 & 0.802 \\
\hline Secondary Modern & 0.870 & 0.200 & 1.093 & 0.442 \\
\hline & & & & \\
\hline Father's class & & 0.056 & & 0.107 \\
\hline Employers, managers, large & 1.267 & 0.260 & 1.055 & 0.812 \\
\hline Employers, managers, small & 1.501 & 0.005 & 1.148 & 0.374 \\
\hline Professional & 1.323 & 0.121 & 1.260 & 0.246 \\
\hline Own account & 1.117 & 0.636 & 1.185 & 0.469 \\
\hline Non-manual & 1.108 & 0.475 & 0.944 & 0.705 \\
\hline Skilled manual & 1.024 & 0.839 & 0.831 & 0.131 \\
\hline Missing & 1.628 & 0.059 & 1.473 & 0.183 \\
\hline Parents' education & & 0.033 & & 0.931 \\
\hline $19+$ & 1.566 & 0.002 & 1.028 & 0.865 \\
\hline $17-18$ & 1.119 & 0.352 & 0.934 & 0.607 \\
\hline 16 & 1.041 & 0.723 & 0.921 & 0.492 \\
\hline Missing & 1.027 & 0.820 & 0.987 & 0.919 \\
\hline Arithmetic 7 & 1.039 & 0.443 & 1.149 & 0.007 \\
\hline Draw-a-man 7 & 0.966 & 0.417 & 1.151 & 0.002 \\
\hline Reading 11 & 1.212 & 0.002 & 1.177 & 0.022 \\
\hline Maths 11 & 1.061 & 0.406 & 1.267 & 0.002 \\
\hline Constant & 0.178 & 0.000 & 0.205 & 0.000 \\
\hline N & 4179 & & 4129 & \\
\hline R ${ }^{2}$ & 0.057 & & 0.036 & \\
\hline
\end{tabular}


Table 5: Sex-type of highest qualification age 33 among those with tertiary qualifications

\begin{tabular}{|l|r|r|r|r|}
\hline & \multicolumn{3}{c|}{ Sex of child } \\
\hline $\begin{array}{l}\text { Sex type of subject } \\
\text { highest qualification }\end{array}$ & \multicolumn{2}{|c|}{ Male } & \multicolumn{2}{c|}{ Female } \\
\hline & Count & \multicolumn{1}{c|}{$\%$} & \multicolumn{1}{c|}{ Count } & $\%$ \\
\hline Female type qualification & 379 & 17.4 & 1312 & 60.1 \\
\hline Male type qualification & 1155 & 53.1 & 304 & 13.9 \\
\hline Integrated type & 643 & 29.5 & 568 & 26.0 \\
\hline Total & 2177 & 100.0 & 2184 & 100.0 \\
\hline
\end{tabular}


Table 6: Wages at age 42, Men Linear Regression of Log hourly pay

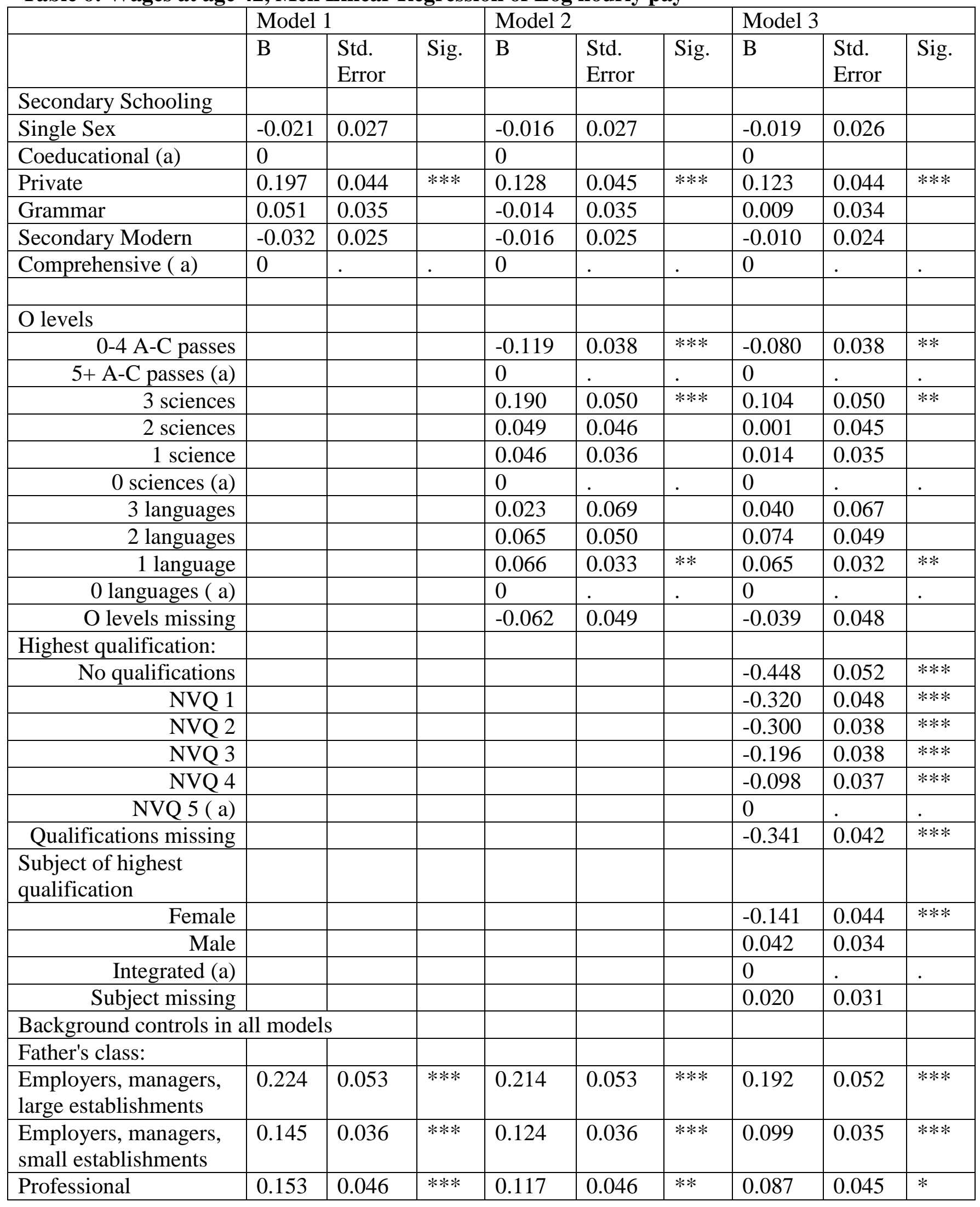




\begin{tabular}{|c|c|c|c|c|c|c|c|c|c|}
\hline Own account & 0.027 & 0.059 & & 0.012 & 0.058 & & -0.012 & 0.057 & \\
\hline Non-manual & 0.133 & 0.033 & $* * *$ & 0.116 & 0.033 & *** & 0.096 & 0.032 & $* * *$ \\
\hline Skilled manual & 0.043 & 0.026 & $*$ & 0.040 & 0.026 & & 0.030 & 0.025 & \\
\hline Unskilled Manual ( a) & 0 & & & 0 & & . & 0 & & \\
\hline Missing & 0.042 & 0.067 & & 0.028 & 0.066 & & 0.021 & 0.065 & \\
\hline $\begin{array}{l}\text { Parents' age leaving FT } \\
\text { education : Missing }\end{array}$ & -0.025 & 0.028 & & -0.029 & 0.028 & & -0.030 & 0.027 & \\
\hline $19+$ & 0.097 & 0.039 & $* *$ & 0.054 & 0.039 & & 0.035 & 0.039 & \\
\hline $17-18$ & 0.036 & 0.029 & & 0.025 & 0.029 & & 0.012 & 0.029 & \\
\hline 16.00 & 0.061 & 0.026 & *** & 0.061 & 0.025 & ** & 0.049 & 0.025 & ** \\
\hline Under 16 & 0 (a) & & & 0 (a) & & . & 0 (a) & & \\
\hline \multicolumn{10}{|c|}{ Childhood cognitive scores } \\
\hline Arithmetic 7 & 0.026 & 0.012 & $* *$ & 0.024 & 0.012 & *** & 0.023 & 0.011 & ** \\
\hline Reading 7 & -0.016 & 0.014 & & -0.013 & 0.014 & & -0.020 & 0.013 & \\
\hline Draw-a-man 7 & 0.032 & 0.010 & $* * *$ & 0.033 & 0.010 & $* * *$ & 0.025 & 0.010 & *** \\
\hline Copy Designs 7 & -0.006 & 0.020 & & $* * *$ & 0.019 & & 0.008 & 0.019 & \\
\hline Verbal reasoning 11 & 0.027 & 0.017 & $*$ & 0.021 & 0.016 & & 0.013 & 0.016 & \\
\hline $\begin{array}{r}\text { Non-verbal reasoning } \\
11 \\
\end{array}$ & 0.068 & 0.015 & $* * *$ & 0.051 & 0.015 & $* * *$ & 0.040 & 0.014 & **** \\
\hline Reading 11 & 0.085 & 0.017 & $* * *$ & 0.057 & 0.018 & $* * *$ & 0.038 & 0.017 & ** \\
\hline Maths 11 & 0.012 & 0.010 & & 0.013 & 0.010 & & 0.009 & 0.010 & \\
\hline Intercept & 2.184 & 0.044 & $* * *$ & 2.328 & 0.059 & **** & 2.541 & 0.066 & $* * *$ \\
\hline $\mathrm{N}$ & 3040 & & & 3040 & & & 3040 & & \\
\hline $\mathrm{R}^{2}$ & 0.212 & & & 0.231 & & & 0.265 & & \\
\hline
\end{tabular}

(a) $=$ reference category; ${ }^{* * *} \mathrm{p}<0.01,{ }^{* *} \mathrm{p}<0.05 ;{ }^{*} \mathrm{p}<0.01$ 
Table 7: Wages age 42, Women: Linear Regression of Log hourly pay

\begin{tabular}{|c|c|c|c|c|c|c|c|c|c|}
\hline & \multicolumn{2}{|c|}{ Model 1} & & \multicolumn{2}{|c|}{ Model 2} & \multirow{2}{*}{ Sig. } & \multicolumn{2}{|c|}{ Model 3} & \multirow{2}{*}{ Sig. } \\
\hline & B & $\begin{array}{l}\text { Std. } \\
\text { Error }\end{array}$ & Sig. & $\mathrm{B}$ & \begin{tabular}{|l} 
Std. \\
Error
\end{tabular} & & $\mathrm{B}$ & $\begin{array}{l}\text { Std. } \\
\text { Error }\end{array}$ & \\
\hline \multicolumn{10}{|l|}{ Secondary Schooling } \\
\hline Single Sex & 0.052 & 0.025 & $* *$ & 0.041 & 0.024 & $*$ & 0.047 & 0.023 & $* *$ \\
\hline \multicolumn{10}{|l|}{ Coeducational (a) } \\
\hline Private & 0.108 & 0.045 & *** & 0.077 & 0.045 & *** & 0.048 & 0.043 & \\
\hline Grammar & 0.069 & 0.032 & *** & 0.018 & 0.033 & & 0.003 & 0.031 & \\
\hline Secondary Modern & -0.052 & 0.023 & $* *$ & -0.037 & 0.023 & & -0.042 & 0.022 & * \\
\hline Comprehensive (a) & 0 &. & . & 0 &. & & 0 &. & . \\
\hline \multicolumn{10}{|l|}{ O level } \\
\hline 0-4 A-C passes & & & & -0.142 & 0.037 & $* * *$ & -0.036 & 0.035 & \\
\hline $5+\mathrm{A}-\mathrm{C}$ passes (a) & & & & 0 & & & 0 & & . \\
\hline 3 sciences & & & & 0.142 & 0.066 & ** & 0.070 & 0.063 & \\
\hline 2 sciences & & & & 0.062 & 0.060 & & 0.003 & 0.057 & \\
\hline 1 science & & & & -0.007 & 0.035 & & -0.015 & 0.033 & \\
\hline 0 sciences (a) & & & & 0 & & & 0 & & . \\
\hline 3 languages & & & & 0.107 & 0.060 & $*$ & 0.036 & 0.057 & \\
\hline 2 languages & & & & 0.050 & 0.043 & & 0.029 & 0.041 & \\
\hline 1 language & & & & 0.082 & 0.028 & $* * *$ & 0.066 & 0.027 & *** \\
\hline 0 languages (a) & & & & 0 & & & 0 & & . \\
\hline $\mathrm{O}$ levels missing & & & & -0.059 & 0.046 & & 0.004 & 0.044 & \\
\hline \multicolumn{10}{|l|}{ Highest qualification } \\
\hline No qualifications & & & & & & & -0.602 & 0.050 & $* * *$ \\
\hline NVQ 1 & & & & & & & -0.558 & 0.046 & $* * *$ \\
\hline NVQ 2 & & & & & & & -0.474 & 0.038 & $* * *$ \\
\hline NVQ 3 & & & & & & & -0.402 & 0.040 & $* * *$ \\
\hline NVQ 4 & & & & & & & -0.131 & 0.037 & $* * *$ \\
\hline NVQ 5 ( a) & & & & & & & 0 & & . \\
\hline Qualifications missing & & & & & & & -0.414 & 0.044 & **** \\
\hline $\begin{array}{l}\text { Subject of highest } \\
\text { qualification :missing }\end{array}$ & & & & & & & -0.056 & 0.031 & $*$ \\
\hline Female & & & & & & & -0.001 & 0.033 & \\
\hline Male & & & & & & & 0.042 & 0.047 & \\
\hline Integrated( a) & & & & & & & 0 (a) & & . \\
\hline Subject missing & & & & & & & -0.056 & 0.031 & $*$ \\
\hline \multicolumn{10}{|c|}{ Background controls in all models } \\
\hline \multicolumn{10}{|c|}{\begin{tabular}{|l|l} 
Father's class & \\
\end{tabular}} \\
\hline $\begin{array}{l}\text { Employers, managers, } \\
\text { large establishments }\end{array}$ & 0.048 & 0.050 & & 0.028 & 0.050 & & & 0.048 & \\
\hline $\begin{array}{l}\text { Employers, managers, } \\
\text { small establishments }\end{array}$ & 0.058 & 0.034 & $*$ & 0.043 & 0.034 & & 0.017 & 0.032 & \\
\hline Professional & 0.119 & 0.048 & *** & 0.090 & 0.048 & $*$ & 0.016 & 0.045 & \\
\hline
\end{tabular}




\begin{tabular}{|c|c|c|c|c|c|c|c|c|c|}
\hline Own account & -0.050 & 0.052 & & -0.056 & 0.051 & & -0.061 & 0.048 & \\
\hline Non-manual & 0.002 & 0.032 & & -0.006 & 0.032 & & -0.026 & 0.030 & \\
\hline Skilled manual & 0.014 & 0.024 & & 0.010 & 0.024 & & -0.016 & 0.023 & \\
\hline Unskilled Manual(a) & 0 & & & 0 & & & 0 & & \\
\hline Missing & 0.218 & 0.068 & ** & 0.191 & 0.068 & **** & 0.169 & 0.064 & *** \\
\hline \multicolumn{10}{|c|}{ Parents' age leaving FT education } \\
\hline $19+$ & 0.174 & 0.037 & **** & 0.151 & 0.037 & $* * *$ & 0.066 & 0.035 & ** \\
\hline $17-18$ & 0.112 & 0.029 & $* * *$ & 0.100 & 0.028 & **** & 0.074 & 0.027 & $* * *$ \\
\hline 16.00 & 0.002 & 0.024 & & 0.004 & 0.024 & & 0.005 & 0.023 & \\
\hline Under 16 (a) & 0 & & & 0 & & & 0 & & . \\
\hline Missing & 0.031 & 0.026 & & 0.037 & 0.026 & & 0.031 & 0.025 & \\
\hline \multicolumn{10}{|c|}{ Childhood cognitive scores } \\
\hline Arithmetic 7 & 0.022 & 0.011 & ** & 0.019 & 0.011 & * & 0.013 & 0.010 & \\
\hline Reading 7 & -0.016 & 0.014 & & -0.012 & 0.014 & & -0.009 & 0.013 & \\
\hline Draw-a-man 7 & 0.016 & 0.010 & * & 0.015 & 0.010 & & 0.016 & 0.009 & $*$ \\
\hline Copy Designs 7 & 0.000 & 0.019 & & 0.003 & 0.019 & & $* * *$ & 0.018 & \\
\hline Verbal reasoning 11 & 0.005 & 0.016 & & 0.000 & 0.016 & & -0.008 & 0.015 & \\
\hline $\begin{array}{r}\text { Non-verbal reasoning } \\
11\end{array}$ & 0.074 & 0.015 & *** & 0.052 & 0.016 & $* * *$ & 0.018 & 0.015 & \\
\hline Reading 11 & 0.066 & 0.017 & $* * *$ & 0.046 & 0.017 & $* * *$ & 0.032 & 0.016 & *** \\
\hline Maths 11 & 0.008 & 0.010 & & 0.008 & 0.010 & & 0.010 & 0.009 & \\
\hline Intercept & 1.964 & 0.041 & **** & 2.102 & 0.055 & $* * *$ & 2.438 & 0.064 & $* * *$ \\
\hline $\mathrm{N}$ & 3169 & & & 3169 & & & 3169 & & \\
\hline $\mathrm{R}^{2}$ & 0.158 & & & 0.172 & & & 0.263 & & \\
\hline
\end{tabular}

(a) $=$ reference category; $* * * \mathrm{p}<0.01, * * \mathrm{p}<0.05 ; * \mathrm{p}<0.01$ 


\section{APPENDIX}

A1: Logistic regression, likelihood of employment age 42 (Only variables of interest shown)*.

\begin{tabular}{|c|c|c|c|c|}
\hline & Men & & Women & \\
\hline & Odds ratio & Sig. & Odds ratio & Sig \\
\hline Single sex & .870 & 396 & 1.019 & .856 \\
\hline School Sector & & 263 & & 329 \\
\hline Private & 1.765 & .120 & 719 & .070 \\
\hline Grammar & 1.124 & .650 & 960 & .779 \\
\hline Secondarv Modern & 1.226 & .151 & 991 & 924 \\
\hline Father's class & & .007 & & 110 \\
\hline Emplovers. managers. large & 2.092 & .076 & 955 & 829 \\
\hline Emplovers. managers. small & 2.626 & .000 & 1.312 & .073 \\
\hline Professional & 1.345 & 337 & 932 & 718 \\
\hline Own account & 1.246 & 475 & 1.712 & 029 \\
\hline Non-manual & 1.896 & 004 & 951 & 708 \\
\hline Skilled manual & 1.141 & 321 & 1.134 & 211 \\
\hline Missing & 1.413 & .374 & .866 & .581 \\
\hline & & & & \\
\hline Parents' age left school (whichever higher) & & .097 & & .855 \\
\hline $19+$ & .672 & 133 & 969 & 421 \\
\hline $17-18$ & .893 & 554 & 1.049 & .752 \\
\hline 16 & 1.011 & .942 & 1.087 & .842 \\
\hline Missing & .703 & 0.019 & .966 & 700 \\
\hline Childhood score & & & & \\
\hline Maths 11 & 1.269 & 0.001 & 1.046 & 537 \\
\hline Constant & 8.092 & .000 & 3.575 & 000 \\
\hline $\mathrm{N}$ & 4273 & & 4503 & \\
\hline $\mathrm{R} 2$ & .039 & & .018 & \\
\hline
\end{tabular}

*The full list of variables reported in the methods section are included in the model, but some are not shown, due to insignificance. 